\title{
PENGEMBANGAN MODEL PENELITIAN PERSPEKTIF GENDER
}

\author{
${ }^{1}$ Nuril Huda, ${ }^{2}$ Aliyah A.Rasyid, ${ }^{3}$ Pujiati Suyata, ${ }^{4}$ Sumarno \\ ${ }^{1)}$ IAIN Antasari Banjarmasin, ${ }^{2,3,4)}$ Universitas Negeri Yogyakarta \\ ${ }^{1)}$ nur.hud2010@gmail.com, ${ }^{3)}$ pujiati_suyata@uny.ac.id, ${ }^{4)}$ sumarno.wonosidi@gmail.com
}

\begin{abstract}
Abstrak
Penelitian ini bertujuan untuk: 1. menggambarkan dan merancang prosedur pengembangan model penelitian berperspektif gender, 2. mengembangkan dan menghasilkan model penelitian berperspektif gender, dan 3. menghasilkan karakteristik model penelitian berperspektif gender. Penelitian ini adalah penelitian pengembangan mengadaptasi model penelitian pengembangan dari Borg dan Gall. Prosedur pengembangan dilakukan melalui sepuluh tahapan, yaitu: 1. studi pendahuluan, 2. perencanaan model, 3. pengembangan model awal, 4.uji coba model awal, 5. revisi model awal, 6.uji coba scope terbatas, 7. revisi uji coba scope terbatas, 8 . pengujian model akhir, 9. revisi model akhir, 10. diseminasi dan implementasi. Penelitian ini dilakukan dengan pendekatan kualitatif. Data dikumpulkan melalui wawancara mendalam, observasi partisipatif, checklist dan dokumentasi. Data dianalisis secara kualitatif dengan teknik analisis kualitatif fenomenologi (grounded) dan dilengkapi dengan analisis gender model HARMOS (modifikasi dari teknik analisis gender model Harvard dan model Moser). Hasil penelitian ini adalah sebagai berikut: 1 . Pengembangan model penelitian berperspektif gender dilakukan dengan mengadaptasi model penelitian dan pengembangan yang dikemukakan oleh Borg dan Gall. 2. Menemukan model penelitian berperspektif gender yang secara spesifik menggunakan analisis gender model HARMOS (modifikasi dari analisis gender model Harvard dan model Moser) dan pedoman aplikasinya. 3. Menghasilkan karakteristik model penelitian berperspektif gender.
\end{abstract}

Kata kunci: pengembangan, model penelitian, perspektif gender

\section{DEVELOPING A MODEL OF RESEARCH WITH GENDER PERSPEKTIF}

\author{
${ }^{1)}$ Nuril Huda, ${ }^{2)}$ Aliyah A.Rasyid, ${ }^{3)}$ Pujiati Suyata, ${ }^{4)}$ Sumarno \\ ${ }^{1)}$ IAIN Antasari Banjarmasin, ${ }^{2,3,4)}$ Universitas Negeri Yogyakarta \\ 1)nur.hud2010@gmail.com, ${ }^{3)}$ pujiati_suyata@uny.ac.id, ${ }^{4)}$ sumarno.wonosidi@gmail.com
}

\begin{abstract}
Absrtact
The objectives of this study are: 1). to describe and to design the procedure of developing a model of research with gender perspective, 2). to develop and to produce a model of research with gender perspective. 3) to produce model's characteristic of research with gender perspective. This research is a research and development using the research model adapted from the Borg and Gall.The development was carried out through ten stages, namely: 1. preliminary study, 2. planning models, 3. developing the initial model, 4. testing the initial model, 5. revising the initial model, 6. testing it with limited scope, 7 . revising the limited scope testing result, 8. testing the final model, 9. revising the final model, and 10. dissemination and implementation. The study used the qualitative research. The data were collected through in-depth interviews, participant observation, checklist and documentaries. The data were analyzed using the qualitative analysis techniques called Phenomenology and gender analysis of the HARMOS model. The results are: 1. The development of the model of gender perspective in the research is carried out using model by Borg and Gall model. 2. Producing the model of the research with gender perspective that specifically used gender analysis HARMOS model and its manual 3. Producing model's characteristic of research with gender perspective.
\end{abstract}

Keywords: development, research model, genderperpecstive 


\section{Pendahuluan}

Allah menciptakan seluruh benda dan makhluk hidup di alam semesta ini secara berpasangan, antara lain: siang dan malam, bulan dan bintang, langit dan bumi, lautan dan daratan, laki-laki dan perempuan. Masing-masing memiliki kelebihan dan kekurangan, semua itu dimaksudkan agar terjadi keseimbangan dan keselarasan di dunia ini sehingga tercipta keadilan dan kedamaian. Keadilan dan kedamaian dapat diwujudkan oleh laki-laki dan perempuan apabila dalam kehidupan mereka terjadi relasi/hubungan gender yang baik dan harmonis.

Hubungan antara laki-laki dan perempuan seringkali amat penting dalam menentukan posisi keduanya. Bentuk hubungan yang bisa berlangsung antara laki-laki dan perempuan merupakan konsekuensi dari pendefinisian perilaku gender yang semestinya oleh masyarakat tertentu yang ditetapkan berdasarkan kelas, gender, ras, etnis dan suku (Mosse, 2007, p. 8). Penetapan perilaku, sikap dan hubungan antara laki-laki dan perempuan yang berbeda berdasarkan kelas, gender dan suku, menjadi salah satu faktor penyebab ketidakadilan gender di masyarakat.

Dewasa ini masalah gender semakin marak diperbincangkan, terlebih lagi setelah pemerintah Indonesia menetapkan isu gender ini dalam semua program pembangunan yang berkelanjutan dalam semua aspek. Gender adalah suatu konsep yang mengacu pada peran-peran dan tanggung jawab lakilaki dan perempuan sebagai hasil konstruksi sosial dan kultural yang dapat diubah sesuai dengan perubahan zaman (Fakih, 2005, p.8). Oleh karena itu isu-isu gender masuk dalam pembangunan di Indonesia.

Realisasi terhadap semua program pembangunan berwawasan gender, mengacu pada kebijakan global seperti: Konferensi Internasional Perserikatan BangsaBangsa (PBB) tentang Perempuan yang pertama tahun 1975 di Mexico dengan tema "Persamaan, Pembangunan, dan Perdamaian", dan menetapkan tahun tersebut sebagai "Tahun Perempuan Internasional". Sebagai tindak lanjut dari konferensi tersebut, pemerintah Indonesia memasukkan isu-isu perempuan dalam Garis-Garis Besar Haluan Negara $(\mathrm{GBHN})$ dan membentuk lembaga khusus yang menangani persoalan perempuan (Trisakti \& Sugiarti, 2006, p. 24).

Pemerintah Indonesia juga membuat program pembangunan dalam bentuk Pengarusutamaan Gender (PUG) dengan Inpres No.9 tahun 2000. Pengarusutamaan gender adalah strategi untuk mewujudkan kesetaraan dan keadilan gender dalam pembangunan, dan aspek gender terintegrasi dalam perumusan kebijakan program dengan kegiatan perencanaan, pelaksanaan, pemantauan dan evaluasi.

Tujuan PUG adalah : 1) membentuk mekanisme untuk formulasi kebijakan dan program yang responsif gender; 2) memberikan perhatian khusus pada kelompokkelompok yang mengalami marjinalisasi, sebagai dampak dari bias gender; 3) meningkatkan pemahaman dan kesadaran semua pihak, baik pemerintah maupun nonpemerintah, sehingga mereka mau bertindak di bidang masing-masing. (Meneg.P.P, 2001, Eri, 2003, p. 240).

Menurut Badan Perencanaan Pembangunan Nasional (Bappenas), PUG bertujuan untuk memacu efektivitas dan efisiensi pemerintah dan masyarakat dalam upaya mewujudkan sistem pemerintahan yang good governance dalam arti demokratis, berkeadilan, terdesentralisi, transparan, responsif, dan aspiratif serta tidak diskriminatif (Bappenas, 2001, Eri, 2003, p. 238). Oleh karena itu, tujuan akhir PUG adalah mencapai keadilan dan kesetaraan gender.

Arah kebijakan tersebut sudah barang tentu perlu dijabarkan ke dalam berbagai program pembangunan termasuk sektor pendidikan. Penumbuhkembangan keadilan dan kesetaraan gender melalui sektor pendidikan jelas sangat strategis dan efektif mengingat: a) pendidikan merupakan proses untuk mentransfer nilai-nilai (value), budaya dan pengetahuan dari generasi ke generasi; b) pendidikan melibatkan jutaan peserta didik yang akan menjadi tulang punggung pembangunan bangsa di masa depan; c) 
pendidikan merupakan proses tanpa henti yang bersifat investasi. Program pengarusutamaan gender dalam bidang pendidikan diterapkan dalam semua jenjang pendidikan dari Sekolah Dasar, Sekolah Menengah sampai Perguruan Tinggi.

Perguruan Tinggi Negeri sebagai salah satu institusi pemerintah yang bergerak dalam bidang pendidikan seyogyanya mengimplementasikan kebijakan tersebut dengan membuat program yang bernuansa gender. Program gender dapat diterapkan melalui aktivitas Tri Dharma Perguruan Tinggi baik pada aspek pendidikan dan pengajaran, penelitian maupun pengabdian masyarakat.

Berbicara tentang Perguruan Tinggi, akhir-akhir ini banyak universitas di Indonesia yang sedang terkena "demam Research University", dalam rangka meningkatkan mutu dan prestasi dirinya di bidang keilmuan atau science. Hal ini merupakan keinginan yang positif dan harus diwujudkan dengan usaha yang maksimal melalui penelitian yang berbasis budaya ilmiah. Budaya ilmiah memiliki tiga sifat yang fundamental, yaitu: hasrat mencari dan menemukan, rasa harga diri dan sifat egaliter bukan hirarkis. Di samping itu, ada beberapa sifat yang harus diimplementasikan dalam dunia Perguruan Tinggi seperti: jujur tak suka berbohong, transparan, dan "tak dapat dibeli" (Soewardi, 2006, p.17), sehingga hasil penelitian yang berbasis budaya ilmiah tersebut akan meningkatkan kualitas atau mutu Perguruan Tinggi.

Hasrat mencari dan menemukan melalui penelitian adalah usaha untuk pemecahan masalah dalam berbagai aspek kehidupan, termasuk permasalahan gender. Usaha untuk mengkaji permasalahan perempuan telah banyak dilakukan baik di Indonesia maupun di negara lainnya. Kehadiran sejumlah penelitian ini di satu pihak menggembirakan, di pihak lain menimbulkan beberapa pertanyaan yang menyangkut kegunaan, tindak lanjut, apa yang belum dan masih perlu diketahui lebih lanjut dan sejauhmana penelitian-penelitian tersebut dapat ditarik generalisasinya (Bailey,1990, Hartati, 2003, p.129).
Sebaliknya secara realitas pengkajian permasalahan gender melalui penelitian belum banyak dilakukan, hal ini disebabkan masih terbatasnya metode penelitian gender. Oleh karena itu penelitian ini adalah salah satu usaha untuk mengkaji permasalahan gender.

Secara realitas permasalahan gender cukup banyak dan perlu dicarikan solusinya, salah satunya adalah dengan melakukan penelitian. Sejauh ini fakta kesenjangan gender belum terungkap secara jelas dalam penelitian, karena peneliti menggunakan model penelitian konvensional yang tidak berperspektif gender, bersifat umum dan tidak spesifik gender, sehingga hasilnya menjadi tidak akurat untuk menggambarkan kesenjangan gender. Sehubungan dengan itu diperlukan aktivitas pengembangan model penelitian berperspektif gender dari aspek metode dan analisis gender.

Pengembangan model penelitian berperspektif gender dimaksud adalah proses mengembangkan model penelitian berperspektif gender dengan mengangkat tema dan isu-isu gender, menyajikan data terpilah sesuai jenis kelamin, menggunakan teknik analisis gender, serta mengakomodasi kepentingan laki-laki dan perempuan secara proporsional dari aspek akses, partisipasi, kontrol dan manfaat.

Tujuan penelitian ini adalah: 1) menggambarkan prosedur atau langkah pengembangan model penelitian berperspektif gender; 2) menghasilkan model penelitian berperspektif gender sesuai standar penelitian; 3) menghasilkan karakteristik/ciri-ciri dari model penelitian berperspektif gender.

\section{Pengembangan Model Penelitian Berperspektif Gender}

Perkembangan ilmu pengetahuan terjadi antara lain disebabkan oleh fitrah manusia sebagai makhluk yang ingin tahu, mencari dan berpihak kepada kebenaran. Di samping itu, manusia juga memiliki sifat banif (akal budi) yaitu keinginan yang tidak terbatas untuk menggapai yang terbaik dalam kehidupannya (Suprayogo \& Tobro- 
ni, 2003, p. 3). Itulah kelebihan manusia dari makhluk lainnya di dunia ini.

Manusia dalam mencari kebenaran dan menggapai yang terbaik dalam hidupnya menggunakan cara ilmiah dan nonilmiah. Pencarian kebenaran dengan cara ilmiah disebut sebagai aktivitas penelitian. Sejak dua dasa warsa terakhir telah terjadi perubahan paradigma pemikiran dalam penelitian dari yang terfokus pada masalah perempuan beralih pada pemikiran tentang sistem dan struktur masyarakat yang tidak adil berdasarkan pada analisis gender (Trisakti \& Sugiarti, 2006, p. 54). Analisis gender adalah alat untuk memahami realitas sosial yang digunakan dalam penelitian untuk mengungkap kesenjangan gender.

Seiring dengan berkembangnya permasalahan penelitian, terutama menyangkut relasi laki-laki dan perempuan yang kurang seimbang sehingga menghasilkan kesenjangan gender, di samping itu model-model penelitian yang ada dirasa belum memadai untuk mengungkap dan memecahkan permasalahan gender. Di sisi lain belum ada model penelitian berperspektif gender, ma$k a$ diperlukan pengembangan model penelitian berperspektif gender.

Pengembangan model penelitian berperspektif gender dimungkinkan dalam rangka menghasilkan produk baru yang sesuai dengan kebutuhan zaman. Pengembangan model dilakukan dengan cara melakukan penelitian dan pengembangan (Research and Development). Penelitian dan pengembangan adalah sebuah strategi atau metode penelitian yang cukup ampuh untuk memperbaiki praktik (Sukmadinata, 2010, p.164). Menurut Sugiyono (2011, p.407) metode penelitian dan pengembangan atau dalam bahasa Inggrisnya Research and Development disingkat $\mathrm{R} \& \mathrm{D}$, adalah metode penelitian yang digunakan untuk menghasilkan produk tertentu, dan menguji keefektifan produk tersebut.

Penelitian dan pengembangan yang dimaksud adalah suatu proses atau langkahlangkah untuk mengembangkan suatu produk/model baru atau menyempurnakan produk yang telah ada, yang dapat diper- tanggungjawabkan. Produk yang dihasilkan berupa software seperti: buku atau modul atau bisa juga hardware seperti: model-model pendidikan, pelatihan, evaluasi, manajemen, dan lain-lain. (Sukmadinata 2010, p.165). Model penelitian R\&D menghasilkan sesuatu benda/produk.

Pengembangan model penelitian berperspektif gender dimaksud adalah proses mengembangkan atau memodifikasi sebuah model penelitian dengan metodologi yang spesifik gender dan sesuai dengan permasalahan gender. Pengembangan model penelitian berperspektif gender menggunakan paradigma dan teori kritis, serta metodologi yang berorientasi pada pendekatan kualitatif dan teknik analisis gender, sehingga hasil penelitian tersebut dapat mengungkap dan mengarahkan alternatif solusi yang tepat terhadap permasalahan gender.

Penelitian berperspektif gender adalah suatu kajian yang dilaksanakan untuk mengungkap dan memahami terjadinya ketimpangan sosial yang disebabkan oleh aspek gender. Esensi penelitian berperspektif gender adalah berusaha mengungkap pengalaman laki-laki dan perempuan dan relasi gender sesuai dengan isu sentral yang perlu mendapat perhatian. Penelitian berperspektif gender bertujuan untuk memahami gejala dan penyebab ketimpangan gender, serta mengembangkan alternatif bagi pemecahan masalah tersebut. Kajian gender mengangkat masalah peran dan partisipasi laki-laki dan perempuan dalam berbagai sektor pembangunan sebagai isu pokok, dalam usaha meningkatkan kesejahteraan dan status lakilaki dan perempuan sebagai mitra sejajar.

Model penelitian yang dikembangkan dalam penelitian ini adalah model penelitian berperspektif gender pada aspek filosofi ilmu yang mencakup: ontologi, epistemologi dan aksiologi. Ontologi terkait dengan hakikat dan materi atau apa yang dikaji dari pengembangan metodologi penelitian berperspektif gender ini. Pengembangan model penelitian berperspektif gender dari aspek ontologi, secara umum model penelitian ini ingin mengangkat kesenjangan relasi lakilaki dan perempuan (gender) secara propor- 
sional, dan mengkaji/mengkritisi permasalahan atau isu-isu gender yang dikonstruksi oleh masyarakat dalam berbagai aspek pembangunan, serta keterbatasan pemahaman atas realitas subjektif tentang permasalahan gender yang didasari pada sosial ekonomi, politik, dan budaya, serta berusaha mencarikan alternatif solusinya.

Aspek epistemologi dilihat dari metode atau cara kerja dari pengembangan model penelitian berperspektif gender yang menghasilkan pengetahuan melalui kekuatan/kemampuan mengkritisi ideologi patriarkhi, dengan cara melakukan uji coba penelitian dalam bidang gender dengan menggunakan pendekatan kualitatif dan teknik analisis gender (mengkaji akses, partisipasi, kontrol, dan manfaat yang didapat laki-laki dan perempuan secara proporsional melalui wawancara mendalam dan observasi partisipatif terhadap kesenjangan gender).

Aspek aksiologi, melihat kegunaan/ manfaat dari penelitian berperspektif gender, yakni dengan menemukan dan mengkritisi permasalahan gender secara rinci/ jelas melalui model penelitian berperspektif gender, maka hasilnya dapat bermanfaat untuk mengatasi atau mengeleminir dan mencarikan solusi terhadap permasalahan gender secara tepat.

\section{Metode Penelitian}

Jenis Penelitian

Pengembangan model penelitian berperspektif gender ini termasuk jenis penelitian dan pengembangan. Penelitian dan pengembangan atau Research and Development (R\&D) adalah sebuah strategi atau metode penelitian yang sangat ampuh untuk memperbaiki praktik (Sukmadinata. 2010, p.164). Menurut Borg dan Gall (1983, p.772) educational research and development is a process used to develop and validate educational product.

Tujuan penelitian pengembangan ini memperoleh temuan/teori/ilmu, dan menjawab kebutuhan akan adanya alat/ perangkat yang dapat digunakan memperbaiki atau meningkatkan kualitas sumber daya manusia
(SDM) (Ali, 2011, p.400). Dengan demikian pengembangan model penelitian ini menjadi penting untuk dilakukan.

Prosedur pengembangan

Pengembangan model penelitian berperspektif gender melalui sepuluh tahapan, seperti dikemukakan Borg dan Gall (1983), yaitu:

1. Studi pendahuluan, dengan cara mengkaji buku-buku dan jurnal penelitian, yang bertema gender atau yang umum dan hasil-hasil penelitian yang relevan.

2. Perencanaan produk awal. Model penelitian berperspektif gender didesain dari aspek ontologi, epistemologi dan aksiologi, meliputi: pendekatan, rancangan atau desain, metode, instrumen penggali data, analisis data, tujuan dan pengguna, komponen-komponen yang ada pada model penelitian berperspektif gender dan penerapannya.

3. Pengembangan/desain model awal. Rancangan model awal penelitian berbentuk prototipe model. Konsep/prototipe awal model penelitian berperspektif gender, terdiri atas: pengertian, paradigma penelitian, tema dan permasalahan, kajian teori, data dan teknik pengumpulan data, analisis data dan laporan penelitian serta cara penerapannya di lapangan.

4. Pengujian produk awal, dengan cara uji coba di atas meja (desk try out atau desk evaluation) terhadap rancangan model penelitian. Uji coba ini bersifat expert judgment, dari para pakar, yaitu: dua orang pakar gender, dua orang pakar bahasa, dan dua orang pakar metodologi penelitian. Analisis menggunakan lembar penilaian dan disempurnakan melalui Focus Group Discussion.

5. Revisi produk awal. Prototipe model penelitian berperspektif gender yang dihasilkan disempurnakan, dengan tujuan mengembangkan spesifikasi rancangan agar menghasilkan prototipe model penelitian berperspektif gender yang baik.

6. Pengujian produk dengan skope terbatas. Desain/rancangan model disem- 
purnakan dan diuji coba dengan scope terbatas, maksudnya terbatas dari segi wilayah yakni hanya satu kota Banjarmasin dan dari jumlah peneliti, yakni hanya dua orang saja.

7. Revisi hasil pengujian skope terbatas. Hasil uji coba dengan skop terbatas dipelajari dan dilakukan revisi/penyempurnaan desain. Penyempurnaan produk awal masih dilakukan pada aspek materi produk, tanpa melihat kelayakan dalam konteks jumlah dan kapasitas subjek penelitian.

8. Pengujian produk akhir dengan skope diperluas, maksudnya perluasan dari segi wilayah penelitian, yaitu dari satu Kota diperluas menjadi Provinsi. Jumlah subjek uji coba pada tahap ini, tetap sama yakni hanya dua orang.

9. Revisi produk akhir. Hasil akhir pengembangan model berupa laporan penelitian tertulis dilakukan analisis akhir untuk mengetahui reliabilitas/kehandalan dari produk yang dihasilkan dan dilakukan revisi akhir sehingga diperoleh produk yang sempurna.

10. Diseminasi dan implementasi. Hasil akhir dari model penelitian berperspektif gender adalah berupa prototipe dan pedoman aplikasinya. Selanjutnya dibuat dalam bentuk buku, untuk didiseminasikan, dan diimplementasikan secara luas pada masyarakat.

\section{Subjek Uji Coba}

Subjek uji coba penelitian ini adalah, dua orang dosen laki-laki dari Universitas Negeri Lambung Mangkurat, dan dua orang dosen perempuan dari IAIN Antasari, yaitu Perguruan Tinggi Negeri di Banjarmasin. Masing-masing dosen melakukan uji coba penelitian secara individual dengan tema yang sama dan metode yang berbeda.

Teknik Pengumpulan dan Analisis Data

Teknik pengumpulan data yang digunakan penelitian ini adalah: observasi partisipatif, cheklist/lembar observasi, wawancara mendalam, dokumentasi, dan melakukan uji coba model. Analisis data menggunakan teknik analisis gender model HARMOS yakni melihat akses/peluang, partisipasi, kontrol, dan manfaat yang didapat laki-laki dan perempuan dalam berbagai aspek pembangunan, kemudian dipadukan dengan analisis kualitatif fenomenologi grounded, dan content analysis.

\section{Hasil Penelitian dan Pembahasan}

\section{Hasil Studi Pendahuluan}

Penelitian diawali dengan studi pendahuluan, yaitu mencermati beberapa hasil penelitian terdahulu tentang gender. Hasil penelitian yang menggunakan metode konvensional dibandingkan dengan hasil penelitian yang menggunakan metode penelitian berperspektif gender, diketahui hasilnya berbeda. Hal tersebut dapat disajikan dalam Tabel 1.

Berdasarkan Tabel 1, diketahui bahwa penelitian bertema gender yang menggunakan model penelitian konvensional/yang tidak berperspektif gender, berbeda dengan penelitian yang menggunakan metode penelitian gender. Perbedaan tersebut adalah: dalam penyajian dan analisis data, dan temuan/simpulan, serta solusi permasalahan, yang tidak spesifik gender. Sebaliknya, hasil penelitian bertemakan gender yang menggunakan model penelitian berperspektif gender, diketahui data disajikan secara terpilah sesuai jenis kelamin dan dirinci dari aspek partisipasi, akses, kontrol, dan manfaat yang didapat laki-laki dan perempuan. Data yang terkumpul disajikan secara rinci, dianalisis dengan teknik analisis gender dari berbagai aspek, maka solusi terhadap permasalahan gender menjadi jelas dan tepat sasaran. Hal tersebut menunjukkan bahwa isu-isu/permasalahan gender yang dicarikan solusinya melalui model penelitian berperspektif gender, maka hasilnya lebih baik dan lebih komprehensif dalam mencarikan alternatif solusi permasalahan gender. 
Tabel 1. Perbedaan Model Penelitian Konvensional dengan Model Penelitian Berperspektif Gender

\begin{tabular}{|c|c|c|c|c|c|c|}
\hline No. & $\begin{array}{c}\text { Model } \\
\text { Penelitian }\end{array}$ & Tema/ judul & Subjek & Data & $\begin{array}{c}\text { Analisis } \\
\text { Data }\end{array}$ & Solusi Masalah \\
\hline 1 & $\begin{array}{l}\text { Penelitian } \\
\text { Konvensional } \\
\text { /yang tidak } \\
\text { berperspektif } \\
\text { gender }\end{array}$ & $\begin{array}{l}\text { Judul boleh } \\
\text { menggunakan } \\
\text { kata } \\
\text { gender/atau } \\
\text { tidak ada kata } \\
\text { gender }\end{array}$ & $\begin{array}{l}\text { Laki-laki, saja, } \\
\text { perempuan, } \\
\text { saja, atau } \\
\text { gabungan } \\
\text { keduanya }\end{array}$ & $\begin{array}{l}\text { Data disajikan } \\
\text { tidak terpilah } \\
\text { menurut jenis } \\
\text { kelamin }\end{array}$ & $\begin{array}{l}\text { Analisis data } \\
\text { bisa secara } \\
\text { kuantitatif } \\
\text { atau kualitatif } \\
\text { atau } \\
\text { perpaduan } \\
\text { keduanya. }\end{array}$ & $\begin{array}{l}\text { Solusi yang } \\
\text { diberikan secara } \\
\text { umum dan tidak } \\
\text { mengemukakan } \\
\text { faktor penyebab } \\
\text { \& isu-isu gender. }\end{array}$ \\
\hline 2 & $\begin{array}{l}\text { Penelitian } \\
\text { Berperspektif } \\
\text { Gender }\end{array}$ & $\begin{array}{l}\text { Judul harus ada } \\
\text { kata Gender } \\
\text { atau } \\
\text { menggunakan } \\
\text { istilah laki-laki } \\
\text { dan perempuan }\end{array}$ & $\begin{array}{l}\text { Terdiri dari laki- } \\
\text { laki dan } \\
\text { perempuan/ } \\
\text { gabungan } \\
\text { keduanya }\end{array}$ & $\begin{array}{l}\text { Data disajikan } \\
\text { terpilah antara } \\
\text { laki-laki dan } \\
\text { perempuan, } \\
\text { dilihat dari } \\
\text { aspek peluang, } \\
\text { partisipasi, } \\
\text { kontrol, dan } \\
\text { manfaat }\end{array}$ & $\begin{array}{l}\text { Analisis data } \\
\text { perpaduan } \\
\text { analisis } \\
\text { kualitatif dan } \\
\text { analisis } \\
\text { gender }\end{array}$ & $\begin{array}{l}\text { Solusi diberikan } \\
\text { secara spesifik, } \\
\text { jelas, } \\
\text { mengemukakan } \\
\text { faktor penyebab } \\
\text { dan isu-isu } \\
\text { gender. Solusi } \\
\text { lengkap dan } \\
\text { tepat. }\end{array}$ \\
\hline
\end{tabular}

Pengembangan Prototipe Model Penelitian Berperspektif Gender (Validasi Konsep)

Tahap ini dilakukan pengembangan model penelitian berperspektif gender, terutama pada bagian analisis data dengan mengembangkan analisis gender model HARMOS yaitu modifikasi/perpaduan dari analisis Model Harvard dan Model Moser. Konsep awal prototipe model penelitian berperspektif gender terdiri atas:

1. Aspek ontologi yang terkait dengan hakikat dan materi yang dikaji pada pengembangan model penelitian berperspektif gender ini yaitu: permasalahan yang terjadi terhadap relasi laki-laki dan perempuan yang terkait dengan sosial ekonomi, politik, dan budaya dalam kehidupan bermasyarakat dianalisis secara kritis dari aspek gender.

2. Aspek epistemologi dilihat dari bagaimana cara kerja model penelitian ini, dalam keterbatasan pemahaman atas realitas subjektif, mulai dari: mengidentifikasi permasalahan gender, mengumpulkan data, menyelidiki penyebab masalah kesenjangan gender dengan teknik observasi partisipatif dan wawancara mendalam, serta melihat secara kontekstual kesenjangan gender dalam peran/aturan, menyajikan, mengolah dan menganalisis data serta menafsirkannya secara kritis terhadap sistem sosial.

3. Aspek aksiologi yaitu dilihat dari kegunaan atau manfaat yang diperoleh masyarakat dari aktivitas pengembangan model penelitian berperspektif gender. Berdasarkan paradigma dan teori kritis, peneliti perlu mengakui nilai-nilai yang dianut dan mengkritisi bias gender yang terjadi di masyarakat, untuk dicarikan alternatif solusinya, dengan demikian permasalahan gender dapat dieliminasi.

Desain konsep awal model penelitian berperspektif gender yang masih tentatif, selanjutnya divalidasi oleh delapan orang penilai, yang terdiri atas enam orang pakar dan dua orang pengguna. Mereka itu adalah dua orang pakar Model Penelitian yang terdiri atas satu orang pakar laki-laki, dan satu orang pakar perempuan, dua orang pakar gender keduanya perempuan, dan dua orang pakar bahasa (satu orang laki-laki dan satu 
orang perempuan). Para pakar ter-sebut memiliki pangkat IVb, IVc, dan IVd dan telah banyak melakukan penelitian. Va-lidasi juga diberikan oleh dua orang peng-guna, yaitu: satu orang dosen laki-laki dan satu orang dosen perempuan sekaligus se-bagai subjek uji coba dalam aplikasi model penelitian berperspektif gender yang sedang dirancang. Validasi dilakukan dengan menggunakan cheklist atau lembar evaluasi. Hasil validasi pakar dan pengguna dapat disajikan dalam tabel berikut:

Tabel 2. Hasil Validasi Pakar terhadap Prototipe Model Penelitian Berperspektif Gender

\begin{tabular}{|c|c|c|c|c|c|c|}
\hline \multirow{3}{*}{ No } & \multirow{3}{*}{ Aspek yang dinilai } & \multicolumn{4}{|c|}{ Rekomendasi Pakar } & \multirow{3}{*}{ Hasil Penilaian Para Pakar } \\
\hline & & \multicolumn{2}{|c|}{ revisi } & \multicolumn{2}{|c|}{ tdk revisi } & \\
\hline & & $\mathrm{L}$ & $\mathrm{P}$ & $\mathrm{L}$ & $\mathrm{P}$ & \\
\hline 1. & $\begin{array}{l}\text { Definisi penelitian } \\
\text { berperspektif gender }\end{array}$ & 3 & 5 & - & - & $\begin{array}{l}\text { Menurut para pakar definisi } \\
\text { masih belum jelas, perlu revisi }\end{array}$ \\
\hline 2. & $\begin{array}{l}\text { Karakteristik model } \\
\text { penelitian }\end{array}$ & 1 & - & 2 & 5 & $\begin{array}{l}\text { Karakteristik harus mengacu } \\
\text { pada equal research and social } \\
\text { theory }\end{array}$ \\
\hline 3. & Paradigma penelitian & - & - & 3 & 5 & Paradigma kritis sudah tepat \\
\hline 4. & $\begin{array}{l}\text { Tema dan masalah } \\
\text { penelitian }\end{array}$ & 3 & 5 & - & - & Istilah gender dipertegas \\
\hline 5. & Kajian teori & 3 & 5 & - & - & $\begin{array}{l}\text { Penggunaan teori kritis harus } \\
\text { konsisten }\end{array}$ \\
\hline 6. & $\begin{array}{l}\text { Data, sumber data, \& } \\
\text { alat pengumpul data }\end{array}$ & - & - & 3 & 5 & Uraian sudah lengkap dan jelas \\
\hline 7. & $\begin{array}{l}\text { Pengolahan dan } \\
\text { penyajian data }\end{array}$ & 1 & 2 & 2 & 3 & $\begin{array}{l}\text { Matriks yang dibuat jangan } \\
\text { hanya bersifat normatif }\end{array}$ \\
\hline 8. & Analisis data & 3 & 5 & - & - & $\begin{array}{l}\text { Perlu dibuat pedoman } \\
\text { aplikasinya }\end{array}$ \\
\hline 9. & Laporan penelitian & 3 & 5 & - & - & $\begin{array}{l}\text { Tampilkan ciri khas penelitian } \\
\text { berperspektif gender. }\end{array}$ \\
\hline
\end{tabular}

Keterangan:

$\mathrm{L}=$ Laki-laki $\mathrm{P}=$ Perempuan (maksudnya komentar pakar laki-laki dan pakar perempuan) Angka: 1, 2, 3, 4, dan 5 menunjukkan jumlah pakar yang menilai.

Tabel 2 merupakan data yang dihimpun berdasarkan validasi pakar dan pengguna terhadap konsep prototipe model penelitian berperspektif gender. Hasil penilaian delapan orang pakar menunjukkan bahwa konsep yang dirancang masih perlu revisi karena kurang tepat, terutama pada 9 (sem-bilan) aspek yaitu: Aspek definisi, ka- rakteristik model penelitian, paradigma dan teori kritis, tema/judul dan masalah penelitian, kajian teori, data, sumber data, serta teknik/alat pengumpulan data. Bagian ana-lisis data, perlu dibuat pedoman aplikasi model penelitian berperspektif gender. Pada laporan penelitian harus ditampilkan ciri khas penelitian berperspektif gender, se- 
hingga jelas perbedaannya dari penelitian yang tidak berperspektif gender.

Banyaknya saran yang diberikan untuk kesempurnaan prototipe tersebut, bermakna bahwa konsep awal prototipe pengembangan model penelitian berperspektif gender yang dikembangkan masih perlu dilakukan revisi pada beberapa bagian yang mendasar dari prototipe tersebut sesuai dengan yang disarankan oleh para pakar dan pengguna. Revisi dilakukan dengan menyempurnakan substansi, kalimat, bahasa dan istilah yang digunakan dalam rancangan prototipe/konsep model penelitian berperspektif gender. Selanjutnya di seminarkan melalui Focus Group Discussion (FGD) dengan para Pakar Gender, Pakar Metodologi Penelitian, dan Pakar Bahasa serta Pakar Evaluasi. FGD terhadap prototipe model penelitian berperspektif gender. Perkembangan prototipe model penelitian berperspektif gender sebelum dan sesudah FGD, sebagai berikut.

Tabel 3. Perkembangan Prototipe Model Penelitian

\begin{tabular}{|c|c|c|c|c|c|}
\hline No. & Kriteria & Definisi & Subjek Penelitian & Analisis Data & $\begin{array}{c}\text { Pedoman } \\
\text { Aplikasi }\end{array}$ \\
\hline 1. & $\begin{array}{l}\text { Sebelum } \\
\text { FGD }\end{array}$ & $\begin{array}{l}\text { Semula } \\
\text { responsif } \\
\text { gender, dan } \\
\text { belum jelas } \\
\text { arahnya }\end{array}$ & $\begin{array}{l}\text { Laki-laki saja, } \\
\text { perempuan saja, } \\
\text { atau gabungan } \\
\text { keduanya }\end{array}$ & $\begin{array}{l}\text { Mixing methods } \\
\text { dan analisis } \\
\text { gender }\end{array}$ & Belum ada \\
\hline 2. & $\begin{array}{l}\text { Sesudah } \\
\text { FGD }\end{array}$ & $\begin{array}{l}\text { Menjadi } \\
\text { berperspektif } \\
\text { gender dan } \\
\text { jelas arahnya }\end{array}$ & $\begin{array}{l}\text { Laki-laki dan } \\
\text { perempuan. }\end{array}$ & $\begin{array}{l}\text { Analisis kualitatif } \\
\text { dan analisis } \\
\text { gender }\end{array}$ & $\begin{array}{l}\text { Sudah ada } \\
\text { Pedoman } \\
\text { aplikasinya }\end{array}$ \\
\hline
\end{tabular}

Keterangan: FGD $=$ Fokus Group Discussion

Tabel 3 di atas menggambarkan perkembangan prototipe model penelitian berperspektif gender yang sedang dikembangkan. Sebelum dilakukan FGD konsep/prototipe belum jelas, seperti: definisi, dan istilah responsif gender diganti dengan berperspektif gender, sehingga dengan demikian definisinya semakin jelas arah dan tujuannya. Selain itu ditambah pedoman aplikasi model penelitian berperspektif gender, sehingga mudah untuk diaplikasikan oleh dosen/peneliti atau mahasiswa sebagai peneliti pemula pada saat pengumpulan data di lapangan.

Banyaknya masukan dan saran yang diberikan oleh para pakar dan pengguna untuk kesempurnaan prototipe model penelitian yang dikembangkan, hal tersebut menunjukkan besarnya dukungan dan apresiasi peserta FGD terhadap pengembangan model penelitian berperspektif gender. Pengembangan selanjutnya adalah pada teknik analisis gender, yang memadukan dan memodifikasi analisis gender model Harvard dan model Moser sehingga menjadi model HARMOS, dengan tujuan mendapatkan data yang lengkap dan analisis gender yang lebih mudah dan komprehensif dalam aplikasinya di lapangan, khususnya bagi peneliti pemula.

Hasil Akhir Prototipe Model Penelitian Berperspektif Gender (Model Final)

Konsep akhir model penelitian berperspektif gender yang disempurnakan sesudah FGD, menghasilkan model final berupa: prototipe model penelitian berperspektif gender, dan pedoman aplikasinya yang siap untuk diaplikasikan dalam bentuk 
penelitian lapangan. Prototipe tersebut, dapat disajikan sebagai berikut.

Pengembangan model penelitian berperspektif gender adalah proses mengembangkan model/pola penelitian berperspektif gender, yaitu model penelitian yang berusaha memecahkan persoalan gender yang terjadi di masyarakat dan menemukan solusinya dengan cara yang spesifik/khas gender.

Model penelitian ini dalam aplikasinya, dimulai dengan mengangkat tema/judul dan isu-isu gender, menyajikan data terpilah sesuai jenis kelamin, menggunakan teknik analisis gender, dan menggunakan pendekatan dan analisis kualitatif, serta mengakomodasi kepentingan laki-laki dan perempuan secara proporsional.

Materi/isi yang dibahas dalam penelitian berperspektif gender adalah permasalahan atau isu-isu gender yang terjadi di masyarakat dalam berbagai bidang pembangunan (seperti bidang kesehatan, pendidikan, ekonomi, sosial, budaya, dan lain-lain) yang menyebabkan ketidakadilan gender. Permasalahan gender tersebut dilihat dari aspek partisipasi, akses/peluang, kontrol, dan manfaat yang diperoleh laki-laki dan perempuan.

Tujuan penggunaan model penelitian berperspektif gender adalah untuk menemukan dan mengungkap permasalahan gender, menyajikan data kesenjangan gender secara rinci berdasarkan jenis kelamin dan menemukan alternatif solusi permasalahan gender secara konkrit. Dengan demikian hasil dari penelitian berperspektif gender dapat bermanfaat antara lain memberdayakan laki-laki dan perempuan secara proporsional dalam berbagai aspek pembangunan, mencarikan alternatif solusi permasalahan gender secara konkrit, dan mengeliminir kesenjangan gender yang terjadi dalam kehidupan bermasyarakat, berbangsa dan bernegara.

Model penelitian berperspektif gender yang dihasilkan dari penelitian ini, dapat digunakan oleh mahasiswa, dosen dan peneliti, serta masyarakat dalam kegiatan penelitian diberbagai sektor pembangunan, baik pada level Perguruan Tinggi maupun masyarakat luas.

Komponen model penelitian berperspektif gender ini adalah: a) definisi penelitian berperspektif gender; b) karakteristik model penelitian berperspektif gender; c) paradigma penelitian; d) tema atau judul dan permasalahan penelitian; e).kajian teori; f). pendekatan penelitian; g) data, sumber data dan teknik pengumpulan data, h) analisis data perpaduan analisis kualitatif dan analisis gender model HARMOS; i). laporan penelitian.

Hasil Akhir Produk/Model Penelitian Berperspektif Gender (Validasi Emperik)

Berdasarkan laporan hasil penelitian yang ditulis oleh dua orang dosen pada uji coba skala terbatas diketahui adanya perbedaan cara penyajian data, pola analisis, temuan dan kesimpulan yang dihasilkan. Penelitian yang menggunakan model penelitian berperspektif gender terbukti lebih rinci, jelas, dan komprehensif dalam mengungkap permasalahan gender, sebab penyajian data ditampilkan dengan tabel-tabel kerja yang mencermati empat aspek yakni, kesempatan mendapatkan peluang atau akses, partisipasi, kontrol dan manfaat terhadap pembangunan yang didapat oleh kaum laki-laki dan perempuan.

Hasil pengamatan dan wawancara yang dilakukan pada kedua orang subyek uji coba penelitian tahap II (skope diperluas) diketahui bahwa para subjek uji coba dalam melakukan penelitian tidak diragukan lagi karena mereka sudah sering melakukan penelitian baik secara individu maupun kelompok dalam bidang keahlian masing-masing dengan menggunakan model konvensional/ yang tidak berperspektif gender yang selama ini sudah familiar di kalangan peneliti.

Penelitian dengan tema gender menurut pengakuan tiga orang subjek uji coba baru kali ini dilakukan, sebelumnya tidak pernah melakukan penelitian, sedangkan satu orang subjek uji coba sudah pernah melakukan penelitian gender dengan analisis gender model Gender Analysis Pathway(GAP), sehingga terlihat dalam mengaplikasikan 
masing-masing model penelitian berbeda, terutama dalam pengumpulan data, penyajian data dan analisis data, yang dapat dilihat dari laporan penelitian secara tertulis. Sehingga diketahui hasilnya juga berbeda.

Hasil laporan penelitian secara tertulis menunjukkan bahwa penelitian dengan menggunakan model penelitian konvensional/yang tidak berperspektif gender hasilnya sangat umum, kurang detail dan tidak mengemukakan solusi terhadap kesenjangan gender karena data yang digali tidak spesifik gender.

Sebaliknya penelitian dengan menggunakan model penelitian berperspektif gender datanya sangat lengkap dan terpilah berdasarkan jenis kelamin dan dilihat dari berbagai profil partisipasi, akses, kontrol dan manfaat, sehingga analisis data, temuan penelitian dan alternatif solusi permasalahan yang diberikan sesuai dengan permasalahan gender/spesifik gender, sehingga temuan dan solusi yang dikemukakan dapat mengeleminir kesenjangan gender, dan pada akhirnya diharapkan dapat mewujudkan keadilan dan kesetaraan gender.

Berdasarkan hasil uji coba tahap I dan tahap II, maka dapat disimpulkan perbedaan antara model penelitian konvensional/ yang tidak berperspektif gender dengan model penelitian berperspektif gender. Perbedaan dilihat dari aspek kelebihan dan kekurangan serta keragaman temuan/hasil yang diperoleh.

Gambaran lebih jelas perbedaaan kedua model penelitian tersebut dapat disajikan dalam Tabel 4.

Tabel 4. Kelebihan dan Kekurangan serta Keragaman Temuan Model Penelitian

\begin{tabular}{|c|c|c|c|c|}
\hline No. & Model penelitian & Kelebihan/Keungulan & Kekurangan & $\begin{array}{l}\text { Tingkat Keragaman } \\
\text { Temuan }\end{array}$ \\
\hline 1 & $\begin{array}{l}\text { Penelitian } \\
\text { Konvensional/yang } \\
\text { tidak berperspektif } \\
\text { gender }\end{array}$ & $\begin{array}{l}\text { Mudah membuat } \\
\text { instrumen pengumpul } \\
\text { data (IPD), karena } \\
\text { data yang digali } \\
\text { bersifat umum. } \\
\text { Keunggulannya dapat } \\
\text { diterapkan pada } \\
\text { semua tema penelitian }\end{array}$ & $\begin{array}{l}\text { Data kurang } \\
\text { lengkap dan tidak } \\
\text { terpilah antara laki- } \\
\text { laki dan perempuan, } \\
\text { serta tidak melihat } \\
\text { dari aspek peluang, } \\
\text { partisipasi, kontrol, } \\
\text { dan manfaat yang } \\
\text { didapat laki-laki dan } \\
\text { perempuan } \\
\text { Analisis data dan } \\
\text { temuan penelitian } \\
\text { bersifat umum }\end{array}$ & $\begin{array}{l}\text { Solusi } \\
\text { permasalahan } \\
\text { bersifat umum, } \\
\text { sehingga kurang } \\
\text { beragam dan } \\
\text { kurang tepat untuk } \\
\text { mengatasi } \\
\text { permasalahan } \\
\text { gender }\end{array}$ \\
\hline 2 & $\begin{array}{l}\text { Penelitian } \\
\text { Berperspektif } \\
\text { Gender }\end{array}$ & $\begin{array}{l}\text { Instrumen pengumpul } \\
\text { data (IPD) jelas dan } \\
\text { lengkap serta data } \\
\text { rinci dan terpilah } \\
\text { antara laki-laki dan } \\
\text { perempuan. } \\
\text { Keunggulannya pada } \\
\text { analisis data yang } \\
\text { lengkap tinjauannya } \\
\text { dalam berbagai aspek }\end{array}$ & $\begin{array}{l}\text { Penerapannya } \\
\text { terbatas pada } \\
\text { penelitian bertema } \\
\text { gender } \\
\text { Memerlukan waktu } \\
\text { yg banyak untuk } \\
\text { membuat instrumen } \\
\text { yg lengkap }\end{array}$ & $\begin{array}{l}\text { Temuan beragam } \\
\text { dan solusi } \\
\text { permasalahan jelas } \\
\text { dan rinci, sehingga } \\
\text { solusi penelitian } \\
\text { dapat } \\
\text { mengeleminasi } \\
\text { kesenjangan } \\
\text { gender }\end{array}$ \\
\hline
\end{tabular}


Tabel 4 di atas menggambarkan perbedaan model penelitian konvensional/yang tidak berperspektif gender dibandingkan dengan model penelitian berperspektif gender dilihat dari aspek kelebihan dan kekurangan serta keragaman temuan/hasil yang diperoleh. Perbedaan yang mendasar adalah pada pembuatan instrumen pengumpul data (IPD) dan data yang digali serta temuan dan solusi permasalahan yang dihasilkan, yang hasilnya menunjukkan bahwa model penelitian berperspektif gender meskipun sulit mempersiapkannya, tetapi mudah diterapkan, data yang diperoleh sangat lengkap dan terpilah menurut jenis kelamin dan hasil penelitian ini mengemukakan solusi permasalahan gender secara jelas, sehingga diharapkan dapat mengeleminir kesenjangan gender. Dengan demikian dapat disimpulkan bahwa penerapan model penelitian berperspektif gender dengan analisis gender model HARMOS pada penelitian ini sangat tepat, guna melihat kesenjangan dan permasalahan gender baik dalam bidang ekonomi maupun dalam bidang pendidikan, dan pada akhirnya dapat mencarikan solusi permasalahan gender dengan tepat pula.

Berdasarkan hasil uji coba lapangan dengan skala besar atau diperluas (tahap II) setelah dilakukan revisi akhir terhadap prototipe yang dikembangkan, dapat dihasilkan prototipe model penelitian berperspektif gender yang mulai sempurna sesuai standar model penelitian. Oleh karena itu, prototipe model penelitian berperspektif gender yang dikembangkan sudah dapat dikatakan sebagai model penelitian yang sesuai standar metodologi penelitian. Selanjutnya model akhir penelitian berperspektif gender dapat disebarluaskan melalui seminar hasil penelitian.

\section{Simpulan}

Pengembangan model penelitian berperspektif gender mengacu pada penelitian dan pengembangan model Borg dan Gall dengan tahapan: studi pendahuluan, membuat desain prototipe model penelitian berperspektif gender melalui FGD dan wokshop, divalidasi oleh pakar gender, pakar penelitian, dan pakar bahasa, serta pengguna. Terakhir uji coba dalam bentuk penelitian dan sosialisasi hasil penelitian dalam bentuk seminar.

Langkah pengembangan model penelitian berperspektif gender: a) menyusun rancang bangun filosofi model penelitian; $b$ ) mendesain konseptualisasi produk awal model penelitian; c) menetapkan komponen dan karakteristik model penelitian; d) melakukan validasi konsep dan validasi empirik.

Hasil akhir dari pengembangan model penelitian berperspektif gender ini berupa produk/model penelitian berperspektif gender dengan analisis gender model HARMOS, dan pedoman aplikasinya. Model penelitian berperspektif gender terdiri atas aspek ontologi, epistemologi dan aksiologi. Aspek ontologi yaitu mengangkat isu-isu/ permasalahan gender yang terjadi di masyarakat. Aspek epistemologi yaitu dengan cara mencermati kesenjangan gender dari aspek partisipasi, akses/peluang, kontrol dan manfaat yang didapat laki-laki dan perempuan dengan teknik observasi partisipatif dan wawancara mendalam dan aspek aksiologi adalah diperolehnya manfaat secara proporsional antara laki-laki dan perempuan dalam berbagai aspek pembangunan. Rangkuman model yang dihasilkan sebagai berikut.

1. Model penelitian berpespektif gender adalah model penelitian yang difokuskan pada isu/permasalahan gender yang dilakukan secara cermat dan sistematis dengan menggunakan teknik analisis gender untuk mengatasi kesenjangan gender.

2. Model penelitian ini dalam aplikasinya, dimulai dengan mengangkat tema/judul dan isu-isu gender, menyajikan data terpilah/terpisah sesuai jenis kelamin, menggunakan teknik analisis gender, dan menggunakan pendekatan dan analisis kualitatif, serta mengakomodasi kepentingan laki-laki dan perempuan secara proporsional.

3. Materi yang dikaji/dibahas dalam model penelitian berperspektif gender adalah permasalahan atau isu-isu gender 
yang terkait dengan kesehatan, pendidikan, ekonomi, sosial, budaya, politik, dan lain-lain yang menyebabkan ketidakadilan gender. Permasalahan tersebut dilihat dari aspek partisipasi, akses /peluang, kontrol, dan manfaat yang diperoleh laki-laki dan perempuan.

4. Tujuan penggunaan model penelitian berperspektif gender adalah untuk menemukan dan mengungkap permasalahan gender, menyajikan data kesenjangan gender secara rinci berdasarkan jenis kelamin dan menemukan alternatif solusi permasalahan gender secara konkrit.

Model penelitian berperspektif gender memiliki karakteristik yaitu: a) mengangkat tema gender; b) objek studinya laki-laki dan perempuan; c) datanya memperhatikan dan mengakomodasi kepentingan laki-laki dan perempuan secara proporsional; d) menganalisis dan mengkritisi kegiatan dan perbedaan peran yang dilakukan laki-laki dan perempuan dalam kehidupan bermasyarakat; e) menganalisis partisispasi, akses, kontrol, dan manfaat yang didapat laki-laki dan perempuan dalam aspek pembangunan; f) mengangkat pengetahuan dan pengalaman laki-laki dan perempuan secara poporsional; g) menemukan dan melakukan kritik terhadap isu-isu gender, serta faktor-faktor penyebab terjadinya kesenjangan gender; $h$ ) menggunakan teknik analisis gender model HARMOS dan analisis kualitatif.

Aplikasi model penelitian berperspektif gender adalah dengan mengikuti cara kerja analisis gender model HARMOS. Analisis gender model HARMOS adalah suatu analisis yang digunakan untuk melihat suatu profil gender dari suatu kelompok sosial, dan peran gender dalam suatu program pembangunan, yang mengutamakan perlunya empat komponen dan interelasi satu sama lain, yaitu: profil partisipasi, profil akses, profil kontrol dan profil manfaat. Selain itu dilihat faktor-faktor penyebab yang menimbulkan pengaruh dan kendala, dan mengidentifikasi keperluan gender jangka pendek dan jangka panjang.

\section{Saran-Saran}

Berdasarkan hasil analisis dan temuan penelitian ini, maka disarankan kepada peneliti, pemerhati gender dan pengambil kebijakan sebagai berikut.

1. Penelitian ini hanya mengembangkan analisis gender model Harvard dan analisis model Moser yang menghasilkan analisis gender model HARMOS, karena itu bagi peneliti lain yang berminat melakukan penelitian gender disarankan mengembangkan model analisis gender seperti: GAP, Munro, dan model lainnya.

2. Permasalahan gender cukup banyak dan aktual untuk diteliti, oleh karena itu disarankan kepada pengambil kebijakan agar mengalokasikan dana atau anggaran secara khusus untuk penelitian gender, di samping penelitian lainnya. Selain itu untuk mengeleminasi kesenjangan gender diberbagai bidang diperlukan dukungan dan kebijakan berperspektif gender, baik dari para Pimpinan Perguruan Tinggi maupun Pemerintah Pusat dan Daerah.

3. Peneliti lain dapat menggunakan analisis gender model Harvard, analisis gender model Moser, dan analisis gender model HARMOS dalam penelitian ilmu-ilmu sosial, karena sangat sesuai dan sudah teruji dalam penelitian ini.

4. Para Peneliti yang tertarik melakukan penelitian gender disarankan untuk menggunakan model penelitian berperspektif gender, karena terbukti dapat mengangkat dan mengarahkan solusi permasalahan gender secara komprehensif dan konkrit.

5. Uji coba penelitian ini terbatas pada ilmu-ilmu sosial, karena itu bagi peneliti yang berminat, bisa melakukan penelitian berperspektif gender pada ilmuilmu eksakta.

\section{Daftar Pustaka}

Ali, Muhammad. (2011) Memahami riset perilaku dan sosial. Jakarta: Pustaka Cendekia Utama 
Bappenas. (2001). Rangkuman pembangunan berperspektif gender. Jakarta: Bappenas

Eri, Rossatria, \& Abdurahman, Shaleh, (2003) Gender Mainstreaming dalam "Pengantar kajian gender".Jakarta : PSW UIN Syarif Hidayatullah.

Fakih, Mansour. (2005). Analisis gender dan transformasi sosial. Yogyakarta: Pustaka Pelajar.

Gall, M.D, Gall, J.P \& Borg,W.R,. (1983). Educational research: an introduction. Boston: Pearson Education, Inc.

Hartati, Netty. (2003). Metodologi penelitian berwawasan gender: Dalam Pengantar Kajian Gender. Jakarta: Pusat Studi Wanita UIN Syarif Hidayatullah kerja sama dengan McGill Project/ IIESP.

Meneg. PP. (2001). Konsep-konsep dasar untuke pengarusutaman gender. Jakarta: Kementrian Pemberdayaan Perempuan.

Mosse, J.C. (2007). Half the worl, half a chance an introduction to gender and development. (Terjemahan Hartian Silawati) Gender dan Pembangunan.
Oxford: Oxfam. (Buku asli terbit tahun 1985).

Moser, C.O.N. (1993). Gender planing and development; theory, practice and training. London: Routledge.

Soewardi, Herman. (2006). Pengembangan paradigma keilmuan IAIN-UIN menuju research university: Dalam Research University. Bandung: Suguda Press.

Sugiyono. (2011). Metode penelitian pendidikan (pendekatan kuantitatif, kualitatif dan $\mathrm{R}$ $\Leftrightarrow D)$. Bandung: Alfabeta.

Sukmadinata, Nana Syaodih. (2010), Metode penelitian pendidikan. Bandung: PT. Remaja Rosda Karya.

Suprayogo, Imam, \& Tobroni. (2003). Metodologi penelitian sosial-agama. Bandung: PT.Rosda Karya

Trisakti \& Sugiarti. (2006). Konsep dan teknik penelitian gender. Malang: Universitas Muhammadiyah Malang. 